\title{
Gripa la femeia gravidă
}

\begin{tabular}{|c|}
\hline Violeta Melinte ${ }^{1,2}$, George Gherlan ${ }^{1,2}$, Ana Maria Veja ${ }^{2}$, Emanoil Ceauşu ${ }^{1,2}$ \\
\hline 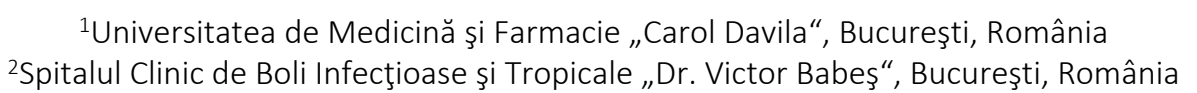 \\
\hline
\end{tabular}

\begin{abstract}
REZUMAT
Femeile gravide cu infecţie gripală sunt predispuse la o formă mai severă de boală decât populaţia generală, conform datelor epidemiologice culese din timpul pandemiilor din 1918-1919, 1957-1958 şi 2009-2010. Severitatea complicaţiilor la gravide pare să fie asociată cu modificările fiziologice din timpul sarcinii: alura ventriculară şi consumul de oxigen cresc, iar capacitatea pulmonară scade. Din cauza riscului crescut pentru a dezvolta forma severă de boală, se recomandă vaccinarea antigripală a gravidelor indiferent de trimestru. În plus, femeile gravide suspectate sau confirmate cu gripă au indicaţie de tratament antiviral, cât mai rapid posibil faţă de debutul simptomatologiei.
\end{abstract}

Cuvinte cheie: sarcină, gripă, vaccinare, antivirale

\section{ETIOLOGIE}

Virusul gripal sau influenza virus face parte din familia Orthomyxoviridae. Este un virus anvelopat, cu forma variabilă, dar frecvent sferic sau filamentos, cu diametru de aproximativ 50-150 nm, cu nucleu ARN linear, monocatenar şi polaritate negativă. Distinctive sunt proiecţiile proteice membranare, reprezentate de hemaglutinina (HA) şi neuraminidaza (NA) în raport HA:NA de 5:1 (1). Există 18 subtipuri de HA şi 11 subtipuri de NA, în funcţie de care sunt caracterizate anual tipurile şi subtipurile tulpinilor virale implicate în patologia sezonieră (ex: H1N1, H3N2 etc.). Tipurile virale recunoscute ca fiind patogene pentru specia umană sunt $\mathrm{A}, \mathrm{B}$ responsabile pentru izbucniri endemice sau pandemice - şi tipul C, care determină afecţiuni respiratorii uşoare (2).

\section{EPIDEMIOLOGIE}

Infecţiile cu virusurile gripale au caracter sezonier. În zonele temperate gripa este raportată începând cu luna octombrie până în aprilie în emisfera nordică şi în perioada mai-septembrie în emisfera sudică (3). În zonele tropicale se înregistrează cazuri de gripă pe tot parcursul anului, dar de obicei au loc una-două epidemii anual (4). Sezonalitatea bolii este multifactorială, incluzând condiţiile de temperatură şi umiditate în care se dezvoltă şi multiplică virusul, precum şi diferenţele de temperatură cald - rece/înăuntru - afară în lunile reci (5).

Cazuri izolate sau focare instituţionale sunt înregistrate pe tot parcursul anului, inclusiv în lunile de vară. Epidemiile în focar au o durată de circa 6-8 săptămâni.

În SUA, în sezonul 2015-2016 au fost raportate 310.000 cazuri spitalizate de infecţii respiratorii cu virusuri gripale. În Europa, în acelaşi sezon au fost raportate 8.500 cazuri spitalizate în 8 ţări, 70\% dintre acestea fiind determinate de tipul viral A (6).

Virusurile gripale se pot transmite la om de la păsări sau porcine, prin contact direct cu animale bolnave sau prin contact cu obiecte sau apă contaminate cu excrementele acestora. Prepararea termică adecvată este indicată pentru diminuarea riscului de infecţie, în cursul epidemiilor de gripă aviară (7). 
Virusurile gripale se transmit de la om la om, prin aerosolii produşi prin tuse sau strănut de către persoanele infectate. În plus, virusul poate fi transmis prin contact direct cu persoanele infectate sau prin contact $\mathrm{cu}$ obiecte şi suprafeţe contaminate. Virusul se răspândeşte rapid, este extrem de contagios, iar perioada de incubaţie este scurtă. O persoană infectată este contagioasă timp de o zi inainte şi 5-10 zile după debutul simptomelor. Copiii pot fi contagioşi o perioadă mai lungă de timp, expunând persoanele din jur la infecţie, în special în colectivitate. Persoanele imunodeficiente pot fi contagioase săptămâni sau chiar luni (8). O epidemie afectează între $30 \%$ şi $60 \%$ dintre persoanele neimunizate ale unei populaţii.

\section{FIZIOPATOLOGIE}

Gripa reprezintă manifestarea clinică a infecţiei cu virus gripal, la persoanele susceptibile, care au inhalat aerosoli contaminaţi. Absenţa anticorpilor neutralizanţi permite multiplicarea virusului la nivelul celulelor mucoasei respiratorii, ceea ce alterează funcţia acestora, conducând în final la liza celulară şi eliberarea de noi virioni. Manifestările clinice sunt expresia eliberării sistemice de mediatori ai inflamaţiei.

Incubaţia variază între 1 şi 4 zile, iar contagiozitatea este prezentă cu o zi înaintea simptomatologiei, ceea ce face posibilă transmiterea virusului de la persoane asimptomatice sau paucisimptomatice (9).

Factorii de virulenţă sunt reprezentaţi de proteinele de suprafaţă - hemaglutinina (HA) şi neuraminidaza (NA). Aceste proteine devin ulterior ţinta anticorpilor protectori specifici. Hemaglutinina aderă la suprafaţa epiteliului permiţând infectarea celulară. Neuraminidaza are rol de a cliva legăturile dintre virionii nou-formaţi şi suprafaţa celulară, ceea ce favorizează diseminarea infecţiei (10).

Virusul influenza este labil din punct de vedere genetic, având o rată a mutaţiilor de 300 de ori mai mare comparativ cu microorganisme (11). ARNpolimeraza virală este deficitară în ceea ce priveşte mecanismele de control al erorilor de transcripţie, ceea ce permite modificări antigenice de tip drift. Acest gen mutaţii apare în permanenţă, fiind responsabil pentru abilitatea virusului de a evita anual, răspunsul imun specific, secundar infecţiilor anteri- oare cu virus gripal. Diferenţele antigenice de tip drift se reflectă în diferenţe de virulenţă a tulpinilor. Driftul antigenic are loc în cadrul aceluiaşi subtip.

Shiftul antigenic este mai puţin frecvent şi implică reasortarea genică a 2 tulpini, foarte probabil în cursul unei co-infecţii la acelaşi organism gazdă. Shiftul antigenic are loc într-o populaţie susceptibilă mai mare, în care sunt posibile forme mai severe de boală. Virulenţa tulpinii este augmentată şi deseori este responsabilă de pandemii.

\section{INFECȚIA MATERNA}

\section{Factori de risc}

Infecţia gripală la gravide cunoaşte de regulă o evoluţie mai severă. Riscul complicaţiilor şi al evoluţiei nefavorabile pare să fie scăzut la gravidele infectate în ultimul trimestru de sarcină si în primele 4 săptămâni postpartum (12).

\section{Manifestări clinice}

În cursul pandemiilor de gripă s-au putut culege informaţii utile cu privire la manifestările clinice ale gripei la gravide.

Înaintea pandemiei de gripă A H1N1 din 2009, gravidele infectate cu virusul influenza erau spitalizate pentru insuficienţă respiratorie acută mai mult decât femeile non-gravide (13).

În timpul pandemiei din 2009 însă, s-a înregistrat un număr disproporţionat de mare de decese în rândul gravidelor ( $5 \%$ din totalul deceselor) în SUA (14).

Gravidele infectate sunt mai expuse riscului de a fi internate pe o secţie de terapie intensivă, faţă de populaţia generală (15). Evoluţia este mai severă la gravidele la care s-a întârziat tratamentul antiviral.

\section{Impactul infecției gripale asupra sarcinii}

Efectele gripei asupra sarcinii nu sunt încă pe deplin investigate. Traversarea barierei placentare pare sa fie rară (16). În orice caz, gripa în sarcină poate afecta evoluţia fătului, chiar şi în absenţa traversării transplacentare, prin efectele sistemice pe care le declanşează. Într-un studiu observaţional din 2013, infecţiile cu virus gripal sau alte infecţii virale de tract respirator în primul trimestru de sarcină au fost asociate cu un risc crescut de anomalii congenitale de tip palatoschizis, hidrocefalie, de- 
fecte în dezvoltarea tubului neural, malformaţii cardiace. Hipertermia şi febra reprezintă manifestări clinice frecvente care cresc riscul pentru disgravidii sau tulburări în dezvoltarea fătului (17). Acest risc pare să fie atenuat prin utilizarea antipireticelor. Alte studii raportează corelaţii între gripă şi avort spontan, naştere prematură, greutate scăzută la naştere, moartea fătului in situ (18). Virusul gripal din perioada pandemiei din 2009 a fost asociat cu un risc ridicat de moarte fetală, în timp ce vaccinarea în sarcină a redus riscul de boală (19).

\section{Impactul sarcinii asupra infecției}

Gravidele sunt expuse riscului de complicaţii secundare infecţiei cu virus gripal în aceeaşi măsură în care sunt expuse femeile non-gravide care au comorbidităţi (Tabelul 1) (20). Riscul creşte odată cu vârsta gestaţională (21).

TABELUL 1. Categorii de pacienți cu risc crescut de complicații

- Copii < 5 ani, și în special < 2 ani

- Adulți > 65 ani

- Gravide și lăuze < 2 săptămâni

- Instituționalizați

- Pacienți cu antecedente de:

- Astm bronșic

- Afecțiuni neurologice

- Afecțiuni cronice respiratorii

- Afecțiuni cardiace

- Afecțiuni hematologice

- Afecțiuni endocrinologice, inclusiv diabet zaharat

- Afecțiuni cronice renale

- Afectiuni cronice hepatice

- Tulburări metabolice

- Copii < 19 ani care primesc aspirină à la long

- Pacienți obezi (IMC >40)

Pneumonia primara virală se manifesta atunci când infecţia virală afectează în special plămânii, şi este de obicei severă. Persistenţa sau agravarea simptomatologiei virale, fără declin - febră, dispnee, tulburări de ventilaţie şi cianoză, sunt sugestive pentru această complicaţie.

Pneumonia secundară bacteriană este anunţată de exacerbarea acuzelor, după o ameliorare iniţială a acestora. Reapar febra şi tusea, iar expectoraţia devinde purulentă. În condiţiile în care s-a constatat că virusul gripal favorizează colonizarea nazală cu S. pneumoniae, acesta din urmă pare să fie etiologia cea mai frecventă a suprainfecţiilor bacteriene în gripă (22), urmat de $S$. aureus (CA-MRSA) (23) şi Haemophilus influenzae (22).

Miozita şi rabdomioliza apar mai frecvent la copii (24). Deşi mialgia este un un simptom definito- riu pentru gripă, miozita este rar întâlnită. În ciuda faptului că prezenţa virală a fost pusă în evidenţă la nivelul celulei musculare, patogenia miozitei nu este încă pe deplin cunoscută. Durerea musculară intensă, în special la nivelul membrelor inferioare, se traduce biologic prin niveluri serice crescute ale creatin fosfokinazei, asociate cu mioglobinurie şi insuficienţă renală acută (25).

Complicaţiile cardiace vizează modificări tranzitorii ale traseului ECG, dar şi infarctul miocardic, miocardita şi pericardita. Riscul pentru infarct pare să fie cel mai mare în primele 7 zile de boală, virusul tip B fiind de 2 ori mai frecvent implicat în aceasta patologie decât virusul tip A, şi de 3 ori faţă de virusul sinciţial respirator (26).

Complicaţiile la nivelul SNC includ encefalopatia, encefalita, mielita transversă, meningita aseptică şi sindromul Guillain-Barré.

Sindromul şocului toxic a fost descris la pacienţii cu gripă - în special cu virus tip B - care au asociat suprainfecţie cu $S$. aureus (27).

\section{Diagnostic prenatal}

Diagnosticul gripei la gravide comportă aceleaşi etape de diagnostic, mai puţin radiografia pulmonară.

Diagnosticul clinic în timpul unei epidemii de gripă este sugerat de orice afecţiune respiratorie febrilă, cu o probabilitate de circa $79 \%$, dacă se întrunesc cel puţin două simptome din patru: tuse, mialgii, odinofagie şi cefalee (28). În afara epidemiei sezoniere, virusurile gripale tip A sau B ocupă doar $10 \%$ din etiologia afecţiunilor respiratorii virale, urmând rinovirusurile (52\%) şi coronavirusurile (26\%), iar diagnosticul clinic este dificil de stabilit (29).

Diagnosticul de laborator presupune confirmarea supoziţiei clinice iniţiale prin intermediul testelor cu fiabilitate variabilă, în funcţie de disponibilitatea acestora în centrele medicale.

Dintre testele moleculare, RT-PCR este cel mai sensibil şi cel mai specific test diagnostic, cu rezultate rapide, care decelează şi subtipul viral (Tabelul 2).

Testele rapide moleculare furnizează rezultate rapide, sub 20 minute, la camera de gardă, cu sensibilitate de $80 \%$ pentru tipul A şi $77 \%$ pentru tipul B, faţă de testele moleculare clasice, la care sensi- 
TABELUL 2. Teste diagnostic pentru virusul influenza

\begin{tabular}{|c|c|c|c|}
\hline Test & $\begin{array}{l}\text { Timp până la } \\
\text { rezultat }\end{array}$ & Probe biologice & Comentarii \\
\hline $\begin{array}{l}\text { RT-PCR convențional și alte teste } \\
\text { moleculare }\end{array}$ & 1-8 ore & $\begin{array}{l}\text { Exsudat nazo-faringian, lavaj } \\
\text { bronșiolar, aspirat tracheal, } \\
\text { spută }\end{array}$ & $\begin{array}{l}\text { Sensibilitate mare și specificitate foarte înaltă; } \\
\text { foarte recomandat; poate diferenția între tipurile } \\
\text { de virus (A și B) și subtipuri }\end{array}$ \\
\hline $\begin{array}{l}\text { Teste rapide moleculare } \\
\text { (detectarea ARN viral) }\end{array}$ & $<20$ min & Exsudat nazal, faringian & $\begin{array}{l}\text { Sensibilitate si specificitate mari; foarte } \\
\text { recomandat; poate diferenția între tipurile de } \\
\text { virus (A și B), dar nu și subtipuri }\end{array}$ \\
\hline Imunofluorescență & 1-4 ore & $\begin{array}{l}\text { Exsudat nazo-faringian, lavaj } \\
\text { bronșiolar, aspirat tracheal }\end{array}$ & $\begin{array}{l}\text { Sensibilitate moderată, specificitate înaltă; } \\
\text { recomandat; diferențiază între tipurile A și B și } \\
\text { alte tipuri virale }\end{array}$ \\
\hline $\begin{array}{l}\text { Detectarea rapidă a antigenului } \\
\text { viral prin imunocromatografie }\end{array}$ & $10-15 \min$ & Exsudat nazo-faringian & $\begin{array}{l}\text { Sensibilitate moderată și specificitate înaltă; } \\
\text { poate diferenția între tipurile A și B și subtipuri }\end{array}$ \\
\hline $\begin{array}{l}\text { Teste rapide (detectarea } \\
\text { antigenului sau neuraminidaza) }\end{array}$ & $<15 \min$ & Exsudat nazo-faringian & $\begin{array}{l}\text { Sensibilitate scăzută/medie și specificitate înaltă; } \\
\text { recomandat; testul negativ nu exclude boala }\end{array}$ \\
\hline Culturi virale & & $\begin{array}{l}\text { Exsudat nazo-faringian, lavaj } \\
\text { bronșiolar, aspirat tracheal, } \\
\text { spută; plasate în mediu de } \\
\text { transport adecvat }\end{array}$ & $\begin{array}{l}\text { Sensibilitate moderată/mare și specificitate } \\
\text { foarte înaltă; recomandat pentru confirmarea } \\
\text { screeningului, și în politica de supraveghere a } \\
\text { sănătății publice; nu este util în managementul } \\
\text { clinic. }\end{array}$ \\
\hline Cultura învelișului viral & $24-72$ ore & & \\
\hline Izolarea din culturi celulare & 3-10 zile & & \\
\hline Teste serologice & & Ser & $\begin{array}{l}\text { Disponibile doar în laboratoare de referință; utile } \\
\text { pentru diagnostic retrospectiv }\end{array}$ \\
\hline
\end{tabular}

bilitatea variază între $92 \%$ şi 95\% pentru tipul A, respectiv B (30).

Testele rapide antigenice se bazează pe metoda imunoserologică de depistare a antigenelor nucleoproteice virale, în probele biologice recoltate de la nivelul căilor respiratorii. Testele furnizează rezultate în circa 15 minute, dar cu o sensibilitate mult scazută faţă de RT-PCR sau testele moleculare rapide, de cca 53-54\% (30).

Testele prin imunofluorescenţă, directe sau indirecte, detectează prezenţa antigenelor virale, dar au sensibilitate şi specificitate scăzute.

Testele imune digitale (Digital immunoassay DIAs) sunt teste rapide care detectează prezenţa antigenelor virale prin imunocromatografie. Rezultatele sunt disponibile în 10-15 minute (31), cu o sensibilitate de circa $80 \%$ (32).

Cultura virală este considerată în mod tradiţional ,gold standard“" pentru diagnosticul de certitudine, dar durează 48-72 ore până la obţinerea rezultatelor. Se însămânţează probe biologice nazale, faringiene, spută sau lavaj bronşiolo-alveolar. $\mathrm{Nu}$ este utilizată de rutină ca test diagnostic, ci ca test de screening şi în monitorizarea sănătăţii publice.
Testele serologice nu sunt utile în diagnosticul infecţiei acute, deoarece necesită recoltarea probelor atât în faza acută, cât şi în cea de convalescenţă, cu determinarea titrului de anticorpi în dinamică. Sunt utile în stabilirea diagnosticului retrospectiv şi în studii de cercetare.

\section{MANAGEMENTUL INFECTTIILOR DIAGNOSTICATE ÎN SARCINĂ}

Tratamentul trebuie început prompt, de la primele simptome sugestive, indiferent de statusul imunizării pentru gripă, în condiţiile în care vaccinul nu este eficient în măsură de 100\% (33). Tratamentul empiric poate fi iniţiat în funcţie de activitatea virusului în comunitate, la momentul respectiv.

Gravidele sau lăuzele sub 2 săptămâni, care au simptome sugestive pentru gripă, necesită tratament empiric prompt, cu medicaţie antivirală. Iniţierea tratamentului cât mai precoce posibil, în primele zile de la apariţia simptomelor, este asociată cu forme mai uşoare de boală şi indice de mortalitate scăzut. Alte studii confirmă beneficiul tratamentului iniţiat şi după 2 zile de boală. Riscul asociat administrării substanţelor antivirale este 
considerat minor, în comparaţie cu beneficiile acesteia, mai ales la gravidele cu forme severe de gripă (34).

Dacă partenerul este diagnosticat cu gripă în timpul sarcinii, nu există repercusiuni asupra fătului şi nici în desfăşurarea procedurilor de reproducerea umană asistată.

Există în prezent un nou agent antiviral - Baloxavir marboxil - aprobat FDA in octombrie 2018, în urma studiilor de fază III, din care au fost excluse femeile gravide. Până se vor obţine mai multe date referitoare la siguranţa acestuia administrat la gravide, oseltamivirul rămâne alegerea de primă intenţie, ca terapie antivirală.

\section{Antivirale}

Inhibitorii de neuraminidază utilizaţi sunt: oseltamivir - per os, zanamivir - inhalator şi peramivir - intravenos. Oseltamivirul, deşi clasă C, este preferat, presupunând că prevalenţa rezistenţei virale este scăzută la tulpinile circulante. Dozele de antiviral sunt aceleaşi ca şi pentru populaţia generală: Oseltamivir $75 \mathrm{mg}$ la 12 ore timp de 5 zile; Zanamivir $10 \mathrm{mg} 2$ inhalaţii pe zi, 5 zile; Peramivir 600 mg i.v. în 15-30 minute ca doză unică (35). Tratamentul poate fi prelungit în formele severe, dincolo de 5 zile, unii clinicieni recomandând şi dublarea dozei (Oseltamivir $150 \mathrm{mg} / z i$ ), deşi nu există dovezi clare ale beneficiului raportat la doză (36).

Forma intravenoasă a medicaţiei antivirale a fost aprobată de FDA în 2014 pentru Peramivir, în prezent lucrându-se la forma i.v. de Zanamivir. Date care să demonstreze eficienţa medicaţiei i.v. sunt indisponibile în acest moment, dar oseltamivirul administrat în formele severe pe sonda nazogastrică pare să fie absorbit în concentraţie suficientă pentru a obţine rezultate favorabile.

\section{Antipiretice}

Acetaminofenul (paracetamolul) este preferat în terapia febrei, în condiţiile în care hipertermia în primul trimestru de sarcină este asociată cu defecte de tub neural sau alte malformaţii congenitale. În plus, prezenţa febrei în timpul travaliului este un factor de risc pentru apariţia convulsiilor neonatale, encefalopatie, paralizie sau deces (37). Alte antipiretice (aspirina, ibuprofen) au fost asociate cu diferite efecte adverse la nou-născut, motiv pentru care nu sunt indicate în febră la gravide.

\section{Antibiotice}

Tratamentul antibiotic este indicat numai în cazurile de suprainfecţie bacteriană a căilor respiratorii superioare (sinuzită, otită) şi inferioare (pneumonie). Tratamentul este similar cu cel pentru populaţia generală, cu excepţia faptului că anumite substanţe cu potenţial teratogen trebuie evitate la gravide (Tabelul 3).

TABELUL 3. Antibiotice contraindicate la gravide

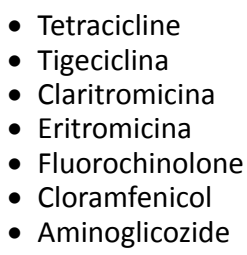

- Tigeciclina

- Claritromicina

- Eritromicina

- Fluorochinolone

- Cloramfenicol

- Aminoglicozide

Gravidele care dezvoltă pneumonie secundară sunt predispuse la naştere prematură (38) şi au risc crescut de edem pulmonar. Se impune deci ca pneumonia bacteriană, complicaţie a gripei la gravide, să fie tratată cu promptitudine. Gravidele sunt predispuse la forme severe de pneumonie, din cauza modificărilor fiziologice care au loc în cursul sarcinii: ascensiunea diafragmului cu până la $4 \mathrm{~cm}$, scăderea capacităţii reziduale, creşterea consumului de oxigen şi retenţia salină (şi apă) la nivel pulmonar. Tratamentul pneumoniei la gravide este sumarizat în Tabelul 4.

Pentru pneumonia comunitară - forma uşoară se recomandă tratament asociat amoxicilină sau amoxicilină-clavulanat şi azitromicină. La pacientele spitalizate se asociază beta-lactamină (ceftriaxonă, cefotaxim, ampicilină-sulbactam) şi azitromicina, iar în formele severe se indică vancomicina ca agent antistafilococic şi antipneumococic MDR.

Alăptarea nu este contraindicată. Virusul nu se transmite prin alăptare. În timpul afecţiunii respiratorii, mama transmite nou-născutului anticorpi materni, imunizându-1, în cazul în care nu este spitalizată. Dacă este necesară separarea celor doi pentru tratamentul intraspitalicesc al mamei, aceasta din urmă trebuie încurajată să îşi menţină lactaţia. Oseltamivirul este foarte puţin eliminat prin lapte şi nu afectează nou-născutul (39), de aceea este indicată continuarea alăptării de către lăuzele cu gripă, chiar dacă sunt sub tratament antiviral. 
TABELUL 4. Algoritm de tratament al pneumoniei la gravide

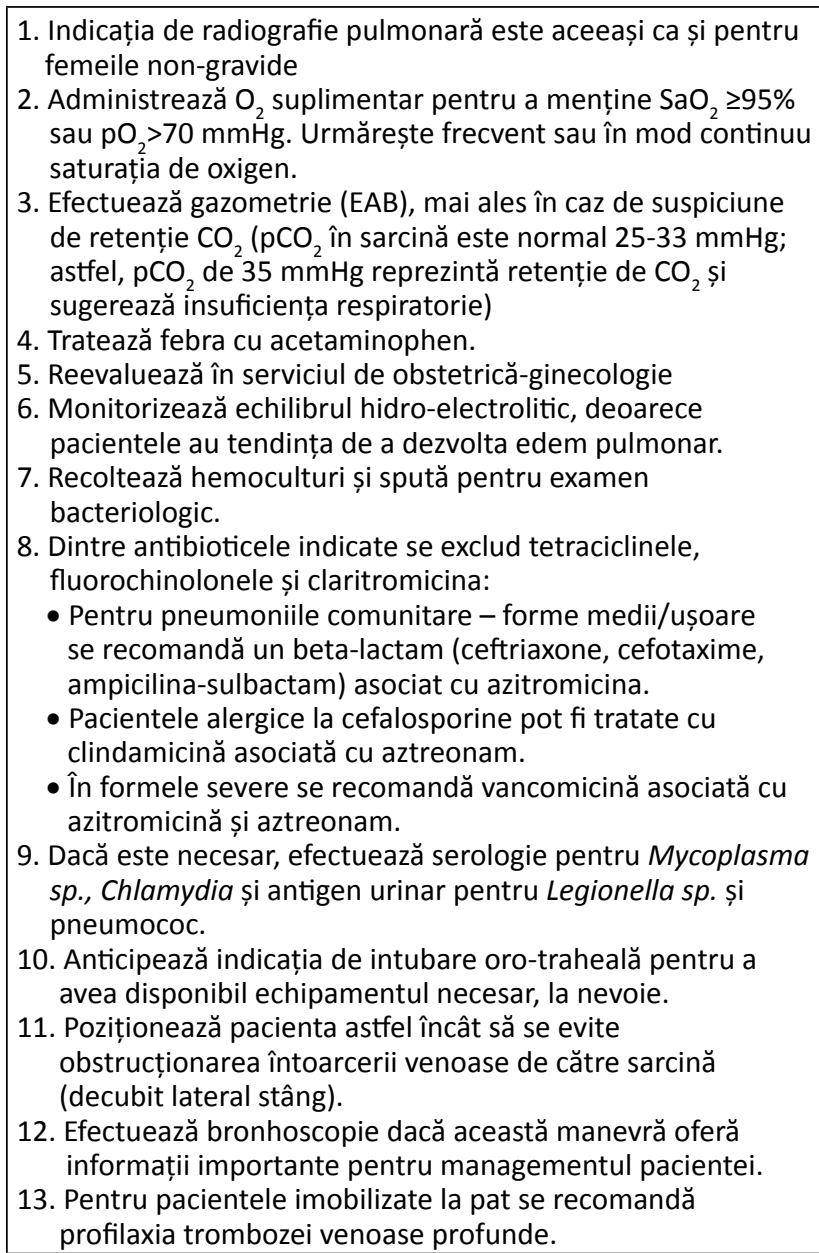

\section{PROFILAXIE}

\section{Vaccinarea}

Din 2004, CDC recomandă vaccinarea tuturor gravidelor cu vaccin cu virus inactivat, indiferent de trimestru (40.) În prezent se comercializează 2 tipuri de vaccin: tetravalent (2 tulpini virus $A$ şi 2 tulpini virus B) şi trivalent (2 tulpini virus A şi o tulpină virus B) fără a fi preferat vreunul în mod particular pentru gravide, în absenţa datelor comparative. Un vaccin recombinat genetic, fără proteină din ou, este disponibil pentru persoanele alergice la ou, inclusiv gravide (41).

Deşi recomandările de vaccinare sunt unanim acceptate, rata imunizării gravidelor rămâne scazută, de numai 36\% în noiembrie 2017 în SUA (42). Rata vaccinării la gravide creşte dacă medicii curanţi recomandă în mod special acest lucru, şi mai ales dacă medicii curanţi recomandă şi administrează vaccinul ei înşişi.

Vaccinul nu este eficient $100 \%$, dar reduce riscul de a dezvolta boala. Gravidele dobândesc imu- nitate pasivă în măsură comparativă cu populaţia generală (43), deşi există mici diferenţe în răspunsul imun la gravide (44). Unele studii au demonstrat ca imunizarea prin vaccinare a fost asociată cu reducerea riscului de sarcină oprită în evoluţie la gravidele cu gripă, dar nu a avut nicio influenţă asupra riscului de avort spontan (45).

Vaccinarea protejează mama, dar şi nou-născutul timp de câteva luni după naştere (46). Imunizarea presupune apariţia anticorpilor anti-influenza de tip IgG, care traversează placenta (47), protejând după naştere nou-născutul, precum şi anticorpi anti-influenza de tip IgA, pe care mama îi transferă copilului prin alăptare (48). Astfel, vaccinarea gravidelor devine un instrument important în profilaxia gripei la nou-născuţi, având în vedere că aceştia sunt expuşi unui risc crescut de a contacta virusul şi de a dezvolta forme severe de boală, în condiţiile în care, până la 6 luni, sugarii nu sunt eligibili pentru profilaxia pasivă, din cauza răspunsului imun insuficient şi ineficient (49). Într-un studiu desfăşurat în Bangladesh, vaccinarea gravidelor în ultimul trimestru de sarcină a condus la scăderea riscului de boală cu $63 \%$ la nou-născuţi în primele 6 luni de viaţă (50).

Deşi în populaţia generală, dar mai ales în rândul gravidelor există îngrijorări cu privire la efectele adverse ale vaccinului, numeroase studii au demostrat că rata acestor evenimente este scăzută, aceeaşi ca pentru populaţia generală. Deşi vaccinarea este asociată cu un risc scăzut pentru sindromul Guillain-Barré, balanţa risc/beneficiu este în favoarea profilaxiei antigripale (51). Un singur studiu pare să evidenţieze o posibilă corelaţie între avortul spontan şi vaccinarea cu produsul conţinând tulpina H1N1 pdm09, administrat în perioada 2010-2011 şi 2011-2012, dar aceste date au nevoie de confirmare prin studii ulterioare (52).

\section{ALGORITMI PENTRU MANAGEMENTUL INFECȚIEI}

Femeile gravide nevaccinate antigripal sunt expuse unui risc înalt (Fig. 1) pentru a dezvolta complicaţii severe secundare infecţiei cu virusul influenza, care pot necesita admisie în compartiment de terapie intensivă. 


\section{Confirmă gripa clinic}

Tabloul clinic include febră $>37.8^{\circ} \mathrm{C}$, plus cel puțin unul dintre urmatoarele criterii:

- tuse

- odinofagie

- rinoree

- cefalee sau mialgii

- astenie

- dispnee

- diaree sau vărsături

- dacă pacienta nu este febrilă dar cu debut acut al simptomatologiei sugestive pentru gripă, continua conform algoritmului

\section{DA}

Monitorizează severitatea simptomatologiei

- Acuză dispnee?

- Acuză o nouă durere sau presiune toracică, fără a fi asociată cu tusea?

- Varsă lichidele ingerate?

- Prezintă semne de deshidratare?

- Prezintă sindrom confuzional?

- A prezentat semne de gripă care s-au ameliorat temporar, urmate de reacutizare?

\section{$\mathrm{NU}$}

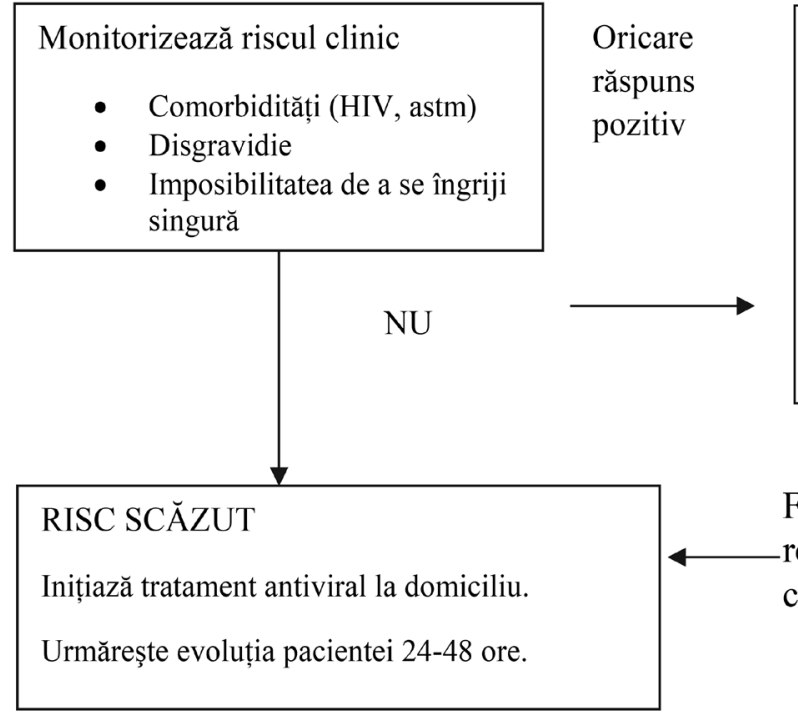
singură

Fără disfuncție respiratorie sau complicații bazic. durilor actuale.
Oricare răspuns

pozitiv

\section{RISC CRESCUT}

Recomandă consult imediat în serviciul de urgență. Dacă este posibil, îndrumă pacienta într-un serviciu în care poate fi izolată. Se va iniția tratament antiviral conform ghidurilor actuale.

\section{RISC MODERAT}

Pacienta va fi examinată în ambulator pentru aprecierea severității afecțiunii. Dacă este posibil, îndrumă pacienta într-o unitate în care poate fi izolată.

Monitorizează funcția respiratorie clinic (SaO2), radiologic sau şi echilibrul acido-

Inițiază tratamentul antiviral conform ghi-

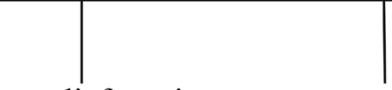

$\mathrm{Cu}$ disfuncție respiratorie sau complicații

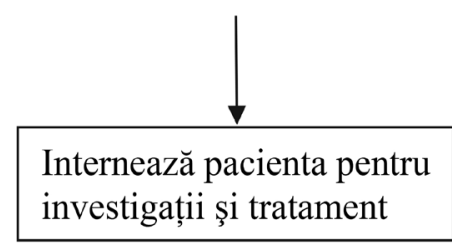




\section{POSOLOGIA TRATAMENTELOR RECOMANDATE}

\begin{tabular}{|c|c|}
\hline Agent antiviral & Doză \\
\hline \multicolumn{2}{|l|}{ Oseltamivir } \\
\hline $\begin{array}{l}\text { Tratament pentru influenzae } \\
\text { A și B }\end{array}$ & $75 \mathrm{mg}$ la 12 ore po, 5 zile \\
\hline \begin{tabular}{|l} 
Profilaxie pentru influenzae \\
A și B
\end{tabular} & 75 mg po zilnic, 10 zile \\
\hline \multicolumn{2}{|l|}{ Zanamivir } \\
\hline $\begin{array}{l}\text { Tratament pentru influenzae } \\
\text { A și B }\end{array}$ & $\begin{array}{l}10 \mathrm{mg} \text { ( } 2 \text { inhalații) la } 12 \text { ore } \\
\text { po, } 5 \text { zile }\end{array}$ \\
\hline \begin{tabular}{|l} 
Profilaxie pentru influenzae \\
A și B \\
\end{tabular} & $\begin{array}{l}10 \mathrm{mg} \text { ( } 2 \text { inhalații) zilnic, } 10 \\
\text { zile }\end{array}$ \\
\hline \multicolumn{2}{|l|}{ Peramivir } \\
\hline $\begin{array}{l}\text { Tratament pentru influenzae } \\
\text { A și B }\end{array}$ & 600 mg i.v. în doză unică \\
\hline
\end{tabular}

\section{BIBLIOGRAFIE}

1. http://www.virology.net/Big_Virology/BVRNAortho.html

2. https://www.cdc.gov/flu/about/viruses/types.htm

3. E Azziz Baumgartner, CN Dao, S Nasreen, et al.: Seasonality, timing, and climate drivers of influenza activity worldwide. J Infect Dis. 206:838-8462012 PMID:22829641

4. S Saha, M Chadha, AAl Mamun, et al.: Influenza seasonality and vaccination timing in tropical and subtropical areas of southern and south-eastern Asia. Bull World Health Organ. 92:318-330 2014 PMID:24839321

5. JD Tamerius, J Shaman, WJ Alonso, et al.: Environmental predictors of seasonal influenza epidemics across temperate and tropical climates. PLoS Pathog. 9:e1003194 2013 PMID:23505366

6. Weekly epidemiological record, nos. 51/52, 16 december 2016)

7. Avian influenza ("bird flu"): fact sheet. World Health Organization. Available at http://www.who.int/mediacentre/factsheets/avian_influenza/en/print.html

8. World Health Organization Writing Group, Bell D, Nicoll A et al. Non-pharmaceutical interventions for pandemic influenza, international measures. Emerg Infect Dis. 2006 Jan. 12 (1):81-7. [Medline]. [Full Text]

9. Gu Y, Komiya N, Kamiya H, Yasui Y, Taniguchi K, Okabe N. Pandemic (H1N1) 2009 transmission during presymptomatic phase, Japan. Emerg Infect Dis. 2011 Sep. 17(9):1737-9.

10. Gubareva LV, Kaiser L, Hayden FG. Influenza virus neuraminidase inhibitors. Lancet. 2000 Mar 4. 355(9206):827-35

11. Drake JW. Rates of spontaneous mutation among RNA viruses. Proc Natl Acad Sci U S A. 1993 May 1. 90(9):4171-5

12. Mertz D, Kim TH, Johnstone J et al. Populations at risk for severe or complicated influenza illness: systematic review and meta-analysis. BMJ 2013; 347:f5061

13. Dodds $L$, McNeil SA, Fell DB et al. Impact of influenza exposure on rates of hospital admissions and physician visits because of respiratory illness among pregnant women. CMAJ 2007; 176:463).

14. Siston AM, Rasmussen SA, Honein MA et al. Pandemic 2009 influenza $\mathrm{A}(\mathrm{H} 1 \mathrm{~N} 1)$ virus illness among pregnant women in the United States. JAMA 2010; 303:1517.

15. Meijer WJ, van Noortwijk AG, Bruinse HW, Wensing AM. Influenza virus infection in pregnancy: a review. Acta Obstet Gynecol Scand 2015; 94:797.

16. Irving WL, James DK, Stephenson T et al. Influenza virus infection in the second and third trimesters of pregnancy: a clinical and seroepidemiological study. BJOG 2000; 107:1282.

17. Luteijn JM, Brown MJ, Dolk H. Influenza and congenital anomalies: a systematic review and meta-analysis. Hum Reprod 2014; 29:809.
Conflict of interest: none declared Financial support: none declared
18. Centers for Disease Control and Prevention (CDC). Maternal and infant outcomes among severely ill pregnant and postpartum women with 2009 pandemic influenza A (H1N1)--United States, April 2009-August 2010. MMWR Morb Mortal Wkly Rep 2011; 60:1193

19. Håberg SE, Trogstad L, Gunnes N et al. Risk of fetal death after pandemic influenza virus infection or vaccination. $\mathrm{N}$ Engl $\mathrm{J}$ Med 2013; 368:333

20. Centers for Disease Control and Prevention. People at high risk of developing flu-related complications. www.cdc.gov/flu/about/disease/ high_risk.htm

21. http://www.influenza.org.nz/impact-influenza-infection-during-pregnancy

22. Bacterial pneumonia during the Hong Kong influenza epidemic of 1968-1969. Schwarzmann SW, Adler JL, Sullivan RJ Jr, Marine WM Arch Intern Med. 1971;127(6):1037

23. S. aureus community-acquired pneumonia during the 2006 to 2007 influenza season. Kallen AJ, Brunkard J, Moore Z, Budge P, Arnold KE, Fosheim G, Finelli L, Beekmann SE, Polgreen PM, Gorwitz R, Hageman J Ann Emerg Med. 2009;53(3):358

24. Acute myositis associated with influenza $B$ infection. Dietzman DE, Schaller JG, Ray CG, Reed ME Pediatrics. 1976;57(2):255

25. Clinical study of influenza-associated rhabdomyolysis with acute renal failure. Abe M, Higuchi T, Okada K, Kaizu K, Matsumoto K Clin Nephrol. 2006;66(3):166.

26. Acute Myocardial Infarction after Laboratory-Confirmed Influenza Infection. Kwong JC, Schwartz KL, Campitelli MA, Chung H, Crowcroft NS, Karnauchow T, Katz K, Ko DT, McGeer AJ, McNally D, Richardson DC, Rosella LC, Simor A, Smieja M, Zahariadis G, Gubbay JB N Engl J Med. 2018;378(4):345

27. Toxic shock syndrome complicating influenza $A$ in a child: case report and review. Tolan RW Jr Clin Infect Dis. 1993;17(1):43

28. Predicting influenza infections during epidemics with use of a clinical case definition. Boivin G, Hardy I, Tellier G, Maziade J Clin Infect Dis. 2000;31(5):1166

29. Acute viral infections of upper respiratory tract in elderly people living in the community: comparative, prospective, population based study of disease burden. Nicholson KG, Kent J, Hammersley V, Cancio E BMJ. 1997;315(7115):1060.)

30. Diagnostic Accuracy of Novel and Traditional Rapid Tests for Influenza Infection Compared With Reverse Transcriptase Polymerase Chain Reaction: A Systematic Review and Meta-analysis. Merckx J, Wali R, Schiller I, Caya C, Gore GC, Chartrand C, Dendukuri N, Papenburg J Ann Intern Med. 2017;167(6):394. Epub 2017 Sep 5.

31. Can newly developed, rapid immunochromatographic antigen detection tests be reliably used for the laboratory diagnosis of 
influenza virus infections? Dunn JJ, Ginocchio CC J Clin Microbiol. 2015;53(6):1790. Epub 2014 Oct 1

32. Diagnostic Accuracy of Novel and Traditional Rapid Tests for Influenza Infection Compared With Reverse Transcriptase Polymerase Chain Reaction: A Systematic Review and Meta-analysis. Merckx J, Wali R, Schiller I, Caya C, Gore GC, Chartrand C, Dendukuri N, Papenburg J Ann Intern Med. 2017;167(6):394. Epub 2017 Sep 5).

33. 2009 pandemic influenza $A$ (H1N1) and vaccine failure in pregnancy. Louie JK, Wadford DA, Norman A, Jamieson DJ Obstet Gynecol. 2011;117(2 Pt 2):470)

34. Severity of 2009 pandemic influenza $A$ (H1N1) virus infection in pregnant women. Creanga AA, Johnson TF, Graitcer SB, Hartman LK, Al-Samarrai T, Schwarz AG, Chu SY, Sackoff JE, Jamieson DJ, Fine AD, Shapiro-Mendoza CK, Jones LE, Uyeki TM, Balter S, Bish CL, Finelli L, Honein MA Obstet Gynecol. 2010;115(4):717

35. http://www.cdc.gov/flu/professionals/antivirals/summary-clinicians. $\mathrm{htm}$

36. Antiviral agents for the treatment and chemoprophylaxis of influenza --- recommendations of the Advisory Committee on Immunization Practices (ACIP). Fiore AE, Fry A, Shay D, Gubareva L, Bresee JS, Uyeki TM, Centers for Disease Control and Prevention (CDC) MMWR Recomm Rep. 2011;60(1):1)

37. (Review: Hyperthermia and fever during pregnancy. Edwards MJ Birth Defects Res A Clin Mol Teratol. 2006;76(7):507

38. Maternal acute respiratory infectious diseases during pregnancy and birth outcomes. Bánhidy F, Acs N, PuhóEH, Czeizel AE Eur J Epidemiol. 2008;23(1):29-35. Epub 2007 Nov 20

39. Oseltamivir and breastfeeding. Wentges-van Holthe N, van Eijkeren M, van der Laan JW Int J Infect Dis. 2008;12(4):451. Epub 2008 Feb 1

40. Prevention and Control of Seasonal Influenza with Vaccines: Recommendations of the Advisory Committee on Immunization Practices - United States, 2017-18 Influenza Season. Grohskopf LA, Sokolow LZ, Broder KR, Walter EB, Bresee JS, Fry AM, Jernigan DB MMWR Recomm Rep. 2017;66(2):1. Epub 2017 Aug 25

41. Influenza vaccination coverage among pregnant women--United States, 2012-13 influenza season. Centers for Disease Control and Prevention (CDC) MMWR Morb Mortal Wkly Rep. 2013;62(38):787).

42. Centers for Disease Control and Prevention. Pregnant women and flu vaccination, Internet Panel Survey, United States, November
2017. https://www.cdc.gov/flu/fluvaxview/pregnant-women-nov2017. $\mathrm{htm}$

43. Benefits of influenza vaccination during pregnancy for pregnant women. Jamieson DJ, Kissin DM, Bridges CB, Rasmussen SAAm J Obstet Gynecol. 2012 Sep;207(3 Suppl):S17-20. Epub 2012 Jul 9

44. Pregnancy modifies the antibody response to trivalent influenza immunization. Schlaudecker EP, McNeal MM, Dodd CN, Ranz JB, Steinhoff MC J Infect Dis. 2012;206(11):1670. Epub 2012 Sep 14

45. Maternal influenza immunization and birth outcomes of stillbirth and spontaneous abortion: a systematic review and meta-analysis. Bratton KN, Wardle MT, Orenstein WA, Omer SB Clin Infect Dis. 2015 Mar;60(5):e11-9. Epub 2014 Nov 18

46. Influenza in Infants Born to Women Vaccinated During Pregnancy. Shakib JH, Korgenski K, Presson AP, Sheng X, Varner MW, Pavia AT, Byington CL Pediatrics. 2016;137(6) Epub 2016 May 2

47. Prevalence of influenza $A$ and $B$ antibodies in pregnant women and their offspring.Wutzler P, Schmidt-Ott R, Hoyer H, Sauerbrei A J Clin Virol. 2009 Oct;46(2):161-4)

48. IgA and neutralizing antibodies to influenza a virus in human milk: a randomized trial of antenatal influenza immunization. Schlaudecker EP, Steinhoff MC, Omer SB, McNeal MM, Roy E, Arifeen SE, Dodd CN, Raqib R, Breiman RF, Zaman K PLoS One. 2013;8(8):e70867. Epub 2013 Aug 14

49. Immunization of high-risk infants younger than 18 months of age with split-product influenza vaccine. Groothuis JR, Levin MJ, Rabalais GP, Meiklejohn G, Lauer BA Pediatrics. 1991;87(6):823

50. K Zaman, E Roy, SE Arifeen, et al.: Effectiveness of maternal influenza immunization in mothers and infants. N Engl J Med. 359:1555-1564 2008 PMID: 18799552

51. Risk of Guillain-Barrésyndrome following H1N1 influenza vaccination in Quebec. De Wals P, Deceuninck G, Toth E, Boulianne N, Brunet D, Boucher RM, Landry M, De Serres G JAMA. 2012 Jul;308(2):175-81

52. Association of spontaneous abortion with receipt of inactivated influenza vaccine containing H1N1pdm09 in 2010-11 and 2011-12. Donahue JG, Kieke BA, King JP, DeStefano F, Mascola MA, Irving SA, Cheetham TC, Glanz JM, Jackson LA, Klein NP, Naleway AL, Weintraub E, Belongia EA Vaccine. 2017;35(40):5314 